\title{
What has Remained of the USSR - Exploring the Erosion of the Post-Soviet Space
}

\author{
Arkady Moshes \& András Racz (red.) \\ Helsinki: Finnish Institute of International Affairs 2019 \\ 264 sider. ISBN 9789517695923
}

Omtalt af Flemming Splidsboel Hansen [Seniorforsker, Dansk Institut for Internationale Studier, fsha@diis.dk]

Mine kolleger på Finnish Institute of International Affairs (FIIA) har fået den glimrende ide at måle, hvor meget der er tilbage af det tidligere Sovjetunionen. Selv forundres jeg ved rejser jævnligt over, dels hvor store ligheder der fortsat er på tværs af de tidligere unionsrepublikker, dels hvor meget de er gledet fra hinanden. Som helhed markerer den postsovjetiske generation sig talentfuldt og stærkt - i blandt andet kulturlivet, økonomien, forskningen og efterhånden det politiske liv - og det kan give anledning til en forventning om en generel og muligvis accelereret udvikling væk fra det fælles sovjetiske.

En bog om "resterne af det tidligere Sovjetunionen« er på flere måder derfor interessant. Den kan for eksempel tilfredsstille vores nysgerrighed efter en vurdering af, hvor sovjetisk det tidligere sovjetiske er i dag. Og den kan fortælle os noget om forudgående og sandsynligvis endda fremtidige udviklingstendenser i det postsovjetiske rum.

Jeg er samlet set begejstret for bogen, men lad mig alligevel starte med et par kritikpunkter. For det første leverer bogen ikke helt som lovet. Mark Galeotti skriver i sit bidrag, at "it is not easy to define a solid starting point for a comparative analysis of the post-Soviet situation« (s. 215), og det gælder for såvel hans kapitel om organiseret kriminalitet som for bogen som helhed. De to redaktører præsenterer ikke et udgangspunkt - en form for sovjetisk normaltilstand - som vi kan bruge i sammenligningen mellem dengang og nu. Hvad var Sovjetunionen egentlig? Bogen er i stedet primært en gennemgang af udvalgte forhold i Sammenslutningen af Uafhængige Stater (SNG). Det gør den godt - men det er noget andet end at måle graden af det sovjetiske.

En sådan måling ville også skulle indeholde de helt bløde aspekter. Det kan for eksempel være nostalgi, sociale normer, kultur- og medieforbrug og kendskab til 
russisk. Det ville have belyst nogle af de områder, som mange bemærker i det daglige, men som få formår at sætte ord og endnu mindre tal på. Et eksempel på et studie af den type er Barbara Törnquist-Plewa og Krzysztof Stalas antologi om Cultural Transformations after Communism (Lund: Nordic Acaademic Press 2011). Moshes og Racz kunne med fordel have skelet til den slags studier for inspiration.

Det andet kritikpunkt er det, at Estland, Letland og Litauen ikke er inkluderet $i$ analyserne. De var alle en del af det tidligere Sovjetunionen, og dette forhold har naturligvis sat sig spor. Effekten var mindre end i mange af de andre republikker, og sporene er mindre tydelige i dag, men studiet af de tre er interessant. Derfor ærgrer det mig, at de alle er ekskluderet. Antologien ønsker blandet annet at sige noget om fremtiden for det postsovjetiske rum - "the area is continuing to disintegrate", som redaktørerne konkluderer (s. 243) - og på den baggrund ville det have været åbenlyst relevant at studere banerne for Estland, Letland og Litauen, som jo hver især og sammen har valgt en kurs væk fra Rusland.

Når det er sagt, er det en oplysende og læseværdig antologi, redaktørerne og forfatterne har sat sammen. Bogen indeholder i alt ni kapitler, som igen er inddelt i tre hovedafsnit: Politik og forsvar, energi og økonomi og til sidst noget om det mere personnære (demografi og migration, religion og kriminalitet). De enkelte kapitler kan stå alene, og hele bogen kan, som nævnt tidligere, læses som en analyse af udvalgte forhold i SNG. I dette aspekt er det et velkomment bidrag.

Alle kapitler er på højt niveau, og forfatterkollektivet er en imponerende liste af eksperter inden for de enkelte områder. Nogle løser dog deres opgaver bedre end andre, og nogle kapitler har mere tyngde end andre. Jeg vil især anbefale kapitlerne om energi (Marc-Antoine Eyl-Mazzega), økonomi (András Deák) og demografi (Lilija Karatjurina), som alle er skatkamre af data. Det er ofte et problem at indsamle troværdige data, og mange forfattere vælger derfor at springe over, hvor det akademiske gærde er lidt lavere. Her får vi til gengæld grafer og tabeller til overflod. Fremhæves skal også Veera Laines fine kapitel om den ortodokse kirke i det postsovjetiske rum. Her er vi inde at berøre nogle af de kulturelle aspekter, som ellers er fraværende i antologien.

Konklusionen fra Moshes og Racz er forholdsvis klar, og den bekræfter det indtryk, som de fleste allerede har: Det postsovjetiske rum falder fra hinanden. På policy-siden anbefaler de på den baggrund en mere differentieret tilgang til de enkelte stater snarere end en fælles skabelon. Fremtidig forskning kan måske hjælpe os til at forstå, hvorledes de tektoniske plader i det postsovjetiske rum glider fra hinanden, og hvor de enkelte stater er på vej hen. Det synes sikkert, at langt de fleste har bevæget sig et godt stykke væk fra Sovjetunionen. Nu er mange af dem så også på vej væk fra det Rusland, som symboliserer det postsovjetiske. 